\title{
MEMBRANE FLUIDITY AND LIPID COMPOSITION OF FLUCONAZOLE RESISTANT AND SUSCEPTIBLE STRAINS OF CANDIDA ALBICANS ISOLATED FROM DIABETIC PATIENTS
}

\author{
Nagendra N. Mishra ${ }^{1 *}$; Tulika Prasad ${ }^{2}$; Neeraj Sharma ${ }^{1}$; Dwijendra K. Gupta ${ }^{1}$ \\ ${ }^{1}$ Department of Biochemistry, University of Allahabad, Allahabad, India; ${ }^{2}$ Membrane Biology Laboratory, School of Life \\ Sciences, Jawaharlal Nehru University, New Delhi, India
}

Submitted: May 08, 2007; Returned to authors for corrections: November 04, 2007; Approved: February 18, 2008.

\begin{abstract}
Ten clinical isolates of Candida albicans, five strains belonging to each of fluconazole resistant and susceptible groups isolated from diabetic patients, were studied for the membrane fluidity and lipid composition. Compared to fluconazole susceptible strains, fluconazole resistant ones exhibited enhanced membrane fluidity as measured by fluorescence polarization technique. The increased membrane fluidity was reflected in the decreased pvalues exhibited by the resistant strains. On the other hand, susceptible isolates contained higher amount of ergosterol, almost twice as compared to resistant isolates which might have contributed to their lower membrane fluidity. However, no significant alteration was observed in the phospholipid and fatty acid composition of these isolates. Labeling experiments with fluorescamine dye revealed that the percentage of the exposed aminophospholipid, phosphatidylethanolamine was highest in the resistant strains as compared to the susceptible strains, indicating a possible overexpression of $C D R 1$ and $C D R 2$ genes in resistant strains. The results presented here suggest that the changes in the ergosterol content and overexpression of $A B C$ transporter genes $C D R 1$ and $C D R 2$ could contribute to fluconazole resistance in C. albicans isolated from diabetic patients.
\end{abstract}

Key-words: membrane fluidity, lipid composition, azole resistance, diabetic patients

\section{INTRODUCTION}

Due to the increase in the number of immunocompromised patients, fungal infections have become more common. Among various human fungal pathogens, $C$. albicans accounts for the majority of systemic infections (27). These pathogenic species of Candida derive their importance not only from the severity of their infection but also from their ability to develop resistance against antifungals (27,35-37). In the recent years, there has been an increase in the incidence of treatment failures in candidiasis patients receiving prolonged fluconazole therapy $(3,10,19,29)$. These treatment failures have been shown to be due to reduced susceptibility of $C$. albicans to fluconazole (28). As advocated by Sanguinetti et al. (30), the mechanisms of resistance to azole antifungal agents have been elucidated in C. albicans and can be mainly categorized as (i) changes in the cell wall or plasma membrane, which lead to impaired azole uptake (ii) alterations in the affinity of the azole drug target, Erg11p (lanosterol $14 \propto$-demethylase) or in the cellular content of Erg $11 \mathrm{p}$ due to target site mutation or overexpression of the $E R G 11$ gene and (iii) the efflux of drugs mediated by membrane transport proteins, $C D R 1$ and $C D R 2$ belonging to the ATPbinding cassette (ABC) transporter superfamily) or members of the major facilitator superfamily (MDRI and FLU1). Candida drug resistance protein $(\mathrm{Cdrlp})$ is a major drug efflux $\mathrm{ABC}$ protein, which plays a key role in the commonly encountered clinical azole resistance in C. albicans (12). A combination of different resistance mechanisms has been reported to be responsible for fluconazole resistance in clinical isolates of $C$. albicans (31).

A close interaction has been shown between membrane lipids and drug extrusion pump proteins $(6,8,33,35-37)$. It has

*Corresponding Author. Mailing address: Department of Biotechnology, S. J. M. Institute of Engineering and Technology, Radaur-135133, Yamunanagar, India. E-mail: nagendranathmishra@yahoo.co.in 
also been observed that the drug resistant $\mathrm{ABC}$ protein of mammalian cells (P-glycoprotein [P-gp]), MDR proteins of yeasts (Pdr5p and Yorlp in Saccharomyces cerevisiae and Cdrlp and Cdr2p in C. albicans) can translocate phospholipids between the two monolayers of the plasma membrane, while P-gp has been shown to participate in sterol homeostasis in mammalian cells $(5,23,24)$. Additionally, these drug extrusion pumps are found to be particularly sensitive to the nature and the changes in the physical state of the surrounding lipids $(9,17,34-36)$. The fact that the lipids could also play an important role in azole susceptibilities is becoming apparent from a host of recent studies. It has been shown that some of the azole-resistant $C$. albicans isolates have exhibited altered membrane sterol compositions $(15,20,21)$. Such lipid changes are observed both in clinical and in vitro adapted azole-resistant isolates $(13,14)$ of C. albicans.

The Cdr1p and Pdr5p are susceptible to fluctuations in the lipid environment, where functions mediated by these drug extrusion pumps are selectively affected $(17,34-37)$. Since the phospholipid composition of the azole resistant and susceptible strains was not altered, the observed fluctuation in ergosterol content appeared to be responsible for the observed changes in membrane order. The alteration exhibited in membrane fluidity was also associated with the changes in membrane lipid asymmetry of azole resistant and susceptible strains. Our results suggest that membrane alterations associated with fluconazole resistance should be an important consideration in delineating the complex mechanism of drug resistance in C. albicans cells.

\section{MATERIALS AND METHODS}

Ten clinical isolates of C. albicans including five azole (fluconazole) resistant, namely DR1, DR2, DR3, DR4 and DR5 with MIC (Minimum inhibitory concentration values expressed in $\mu \mathrm{g} / \mathrm{ml}$ ) values of 64, 64, 62, 64 and 62 respectively and four azole susceptible isolates, DS1, DS2, DS3, DS4 and DS5 with respective MIC values of $8,7,0.5,0.2$, and $2.0 \mu \mathrm{g} / \mathrm{ml}$ were collected from diabetic patients.

MIC of the strains was determined using broth microdilution method and reading of the endpoints was taken at $48 \mathrm{~h}$. The MIC test end point was defined as the lowest drug concentration that gave $>80 \%$ inhibition of growth compared with drug-free controls $\left(\mathrm{MIC}_{80}\right)$. For all experimental studies, the yeast cells were maintained on yeast extract-peptone-dextrose (YEPD) medium at $37^{\circ} \mathrm{C}$.

Ergosterol was extracted as described earlier by Ansari et al. (1) and quantified as described previously by ArthingtonSkaggs et al. (2).

The steady-state fluorescence polarization measurements on yeast cells were carried out essentially as described earlier Ansari et al. (1). Measurements were carried out on whole cells by using a fluorescent probe, 1,6-diphenyl-1, 3,5-hexatriene
(DPH). Fluorescence polarization was measured at excitation and emission wavelengths of 360 and $426 \mathrm{~nm}$, respectively. The measured fluorescence intensities were corrected for background fluorescence and the light scattered from the unlabeled samples.

Phospholipids were extracted separated on thin layer chromatography (TLC) plates and then estimated essentially according to the method given by Ibrahim and Ghannoum (16).

Fatty acids were extracted by refluxing with ethanolic $\mathrm{KOH}$ as per the method described by Ibrahim and Ghannoum (16). After methanolysis the fatty acids were then estimated by the use of gas liquid chromatography (GLC) according to the procedure adopted by above authors.

Fluorescamine, a fluorescent probe which specifically labels exposed aminophospholipids (7), was used for labeling of phosphatidylethanolamine in the outer mono layer of the resistant and susceptible strains of $C$. albicans. Cells were harvested in mid-log phase by centrifuging at 3,000 rpm (Beckman model TJ-6) for $5 \mathrm{~min}$ at $4^{\circ} \mathrm{C}$ and washed two to three times with buffer $\mathrm{A}(100 \mathrm{mM}$ potassium phosphate- $5 \mathrm{mM}$ EDTA, $\mathrm{pH}$ 7.5). The harvested cells ( $0.6 \mathrm{~g}$ wet weight) were resuspended in $5 \mathrm{ml}$ of buffer $\mathrm{B}(100 \mathrm{mM}$ potassium phosphate and $600 \mathrm{mM}$ $\mathrm{KCl}, \mathrm{pH}$ 8.2) and kept at 4 ÚC with gentle swirling. Fluorescamine $(15.6 \mathrm{mM})$ in dehydrated dimethyl sulfoxide was added dropwise to the cell suspension with constant gentle swirling. After $30 \mathrm{~s}$ the reaction was stopped by adding an equal volume of $1 \mathrm{M}$ ammonia in $600 \mathrm{mM} \mathrm{KCl}$. The cells were centrifuged and washed at $4^{\circ} \mathrm{C}$ three to four times till the color of the dye disappeared from the supernatant. Resolved phospholipids and derivatized phosphatidylethanolamine were scraped off from TLC plates, and their phosphate content was estimated (16).

\section{RESULTS AND DISCUSSION}

The amount of ergosterol in fluconazole susceptible isolates was much higher, almost twice as compared to fluconazole resistant isolates (Fig.1). Azole resistance in Candida albicans is known to occur primarily through $E R G 11$, which encodes for $14 \propto$ - lanosterol demethylase, an enzyme involved in ergosterol biosynthesis. Inhibition of this step in ergosterol biosynthesis by fluconazole ultimately leads to accumulation of high levels of toxic 14 -methylated sterols, causing disruption of membrane structure $(11,22)$. Accordingly, any alteration in Erg11p would affect the affinity of the drug for the target leading to resistance in such isolates $(18,25,38,39)$. In view of these observations, it could be assumed that point mutation in the ERG11 gene encoding demethylase enzyme would contribute to resistance through decreased levels of ergosterol. This fact has been exploited in several reports wherein many point mutations in Erg11p has been identified in response to azoles (22).

The decreased amount of ergosterol in fluconazole resistant strains was further reflected in increased membrane fluidity (low 


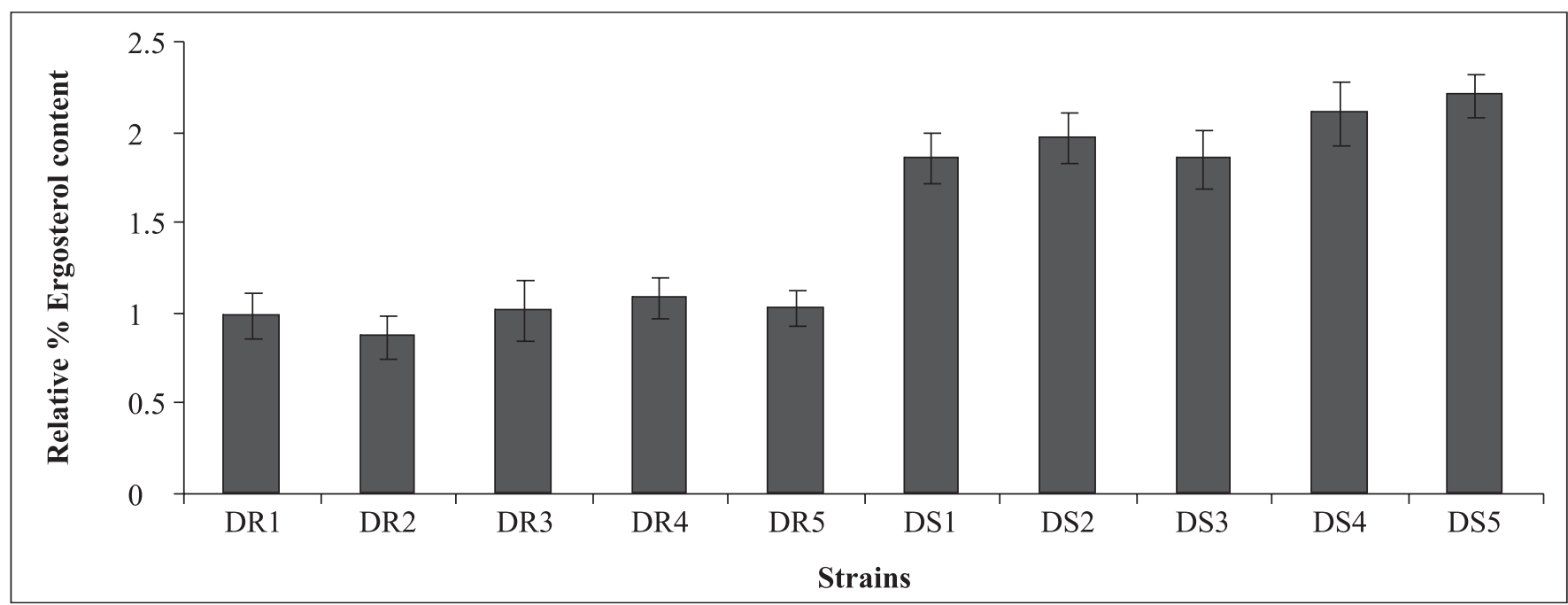

Figure 1. Ergosterol content (\%) in azole resistant and susceptible strains of Candida albicans isolated from diabetic patients. Mean ergosterol content of the cells is expressed as a percentage of the wet weight of the cells \pm the standard deviation of the mean of the three sets of experiments and ergosterol quantitation was done as described in the materials and methods.

p-value) as determined by the use of the fluorescent probe DPH (Fig. 2). Contrary to this, susceptible isolates accordingly had higher p-values which indicated lower membrane fluidity, which is known to have a direct bearing on drug efflux, making itself one of the important molecular mechanisms of antifungal resistance $(27,37)$.

In the present study also, since resistant strains had inverse relationship between ergosterol content and membrane fluidity, this further supported the contention that perhaps the resistance to fluconazole in the present clinical isolates was due to increased efflux pump activity as a result of increased membrane fluidity and decreased ergosterol. This assumption is further strengthened by recent studies where fluconazole resistant isolates have been shown to overexpress efflux pumps namely, $C D R 1$ and $C D R 2$, encoding multidrug efflux transporter proteins belonging to $\mathrm{ABC}$ transporter and CaMDRl belonging to MFS

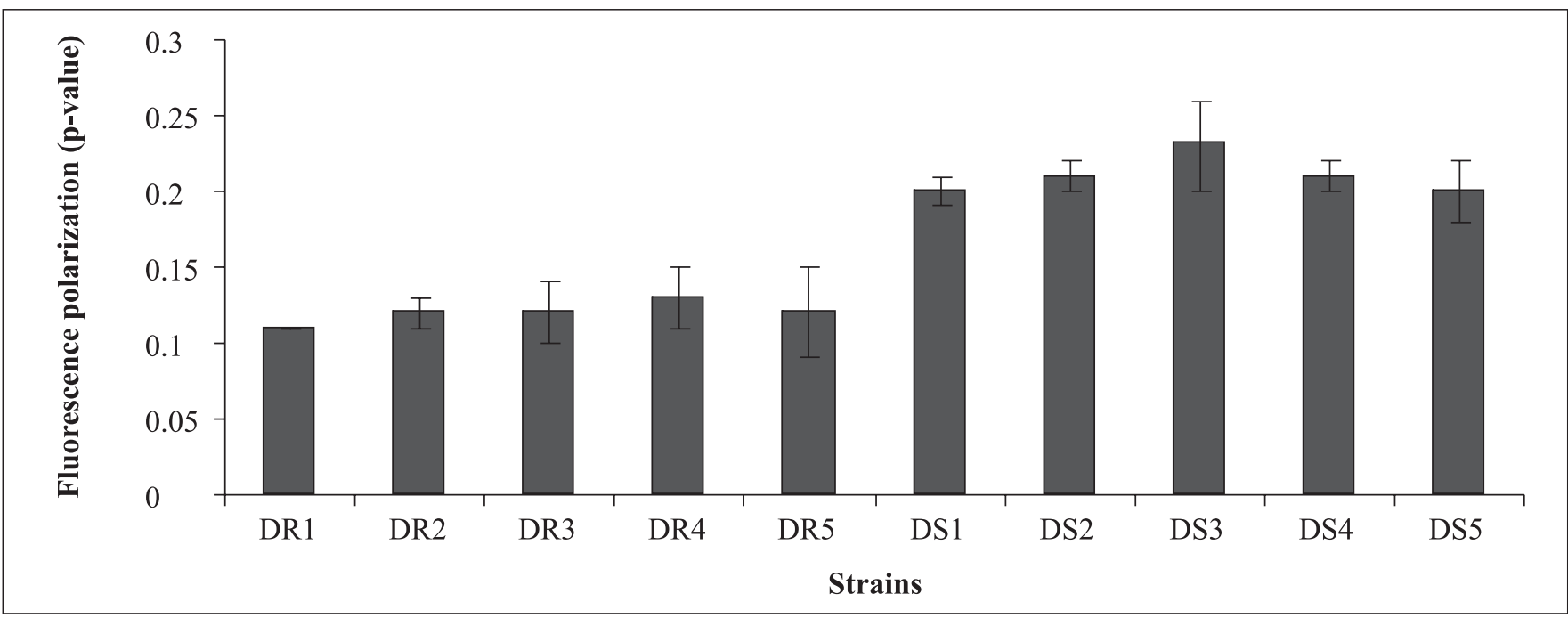

Figure 2. Membrane fluidity of azole resistant and susceptible strains of Candida albicans isolated from diabetic patients as determined by fluorescence polarization and expressed as mean fluorescence polarization " $p$ " values of the cells ( $p$ value is inversely proportional to membrane fluidity) \pm the standard deviation of the mean of the three sets of experiments . 
class of transporters $(26,32)$. Cdr1p and Cdr2p represent two major drug extrusion pumps of $C$. albicans, effluxing not only azoles and their derivatives but also a wide variety of structurally unrelated compounds (27). Cannon's group has recently characterized allelic variations of drug extrusion proteins of Candida, representing an interesting possibility contributing to azole resistance in C. albicans (4). The phospholipids (Fig.3) and fatty acid (Fig.4) composition of the clinical isolates did not contribute to observed changes in fluidity, since they did not show significant differences between the resistant and susceptible strains (13).
Aminophospholipids are present primarily in the inner monolayer of the membrane and phospholipid translocation between the two monolayers of the lipid bilayer of the plasma membrane of $C$. albicans is maintained by an energy-dependent process mediated by the $\mathrm{ABC}$ transporter protein $\mathrm{Cdr} 1 \mathrm{p}(8,20$, 30). Since Cdrlp functioning is also susceptible to alterations in membrane fluidity (34), we investigated the differences in the asymmetrical distribution of phospholipids by labeling with fluorescamine and quantitated aminophosphopholipids translocated to the outer monolayer in these clinical isolates (Fig.5). Since entire phosphatidylserine is localized predominantly

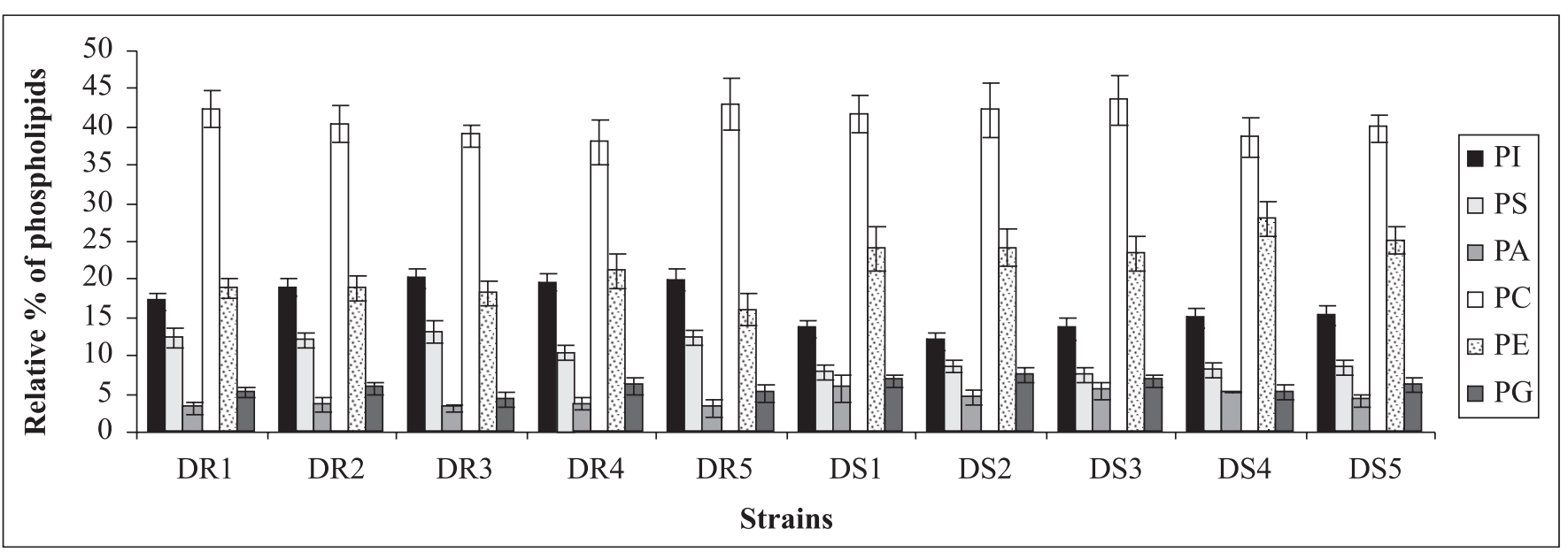

Figure 3. Relative percentage of phospholipids in azole resistant and susceptible strains of Candida albicans isolated from diabetic patients. Abbreviations used: PI, phosphatidylinositol; PS, phosphatidylserine; PA, phosphatidic acid; PC, phosphatidylcholine; PE, phosphatidylethanolamine; PG, phosphatidylglycerol. Each value in the figure is the mean of three independent experiments.

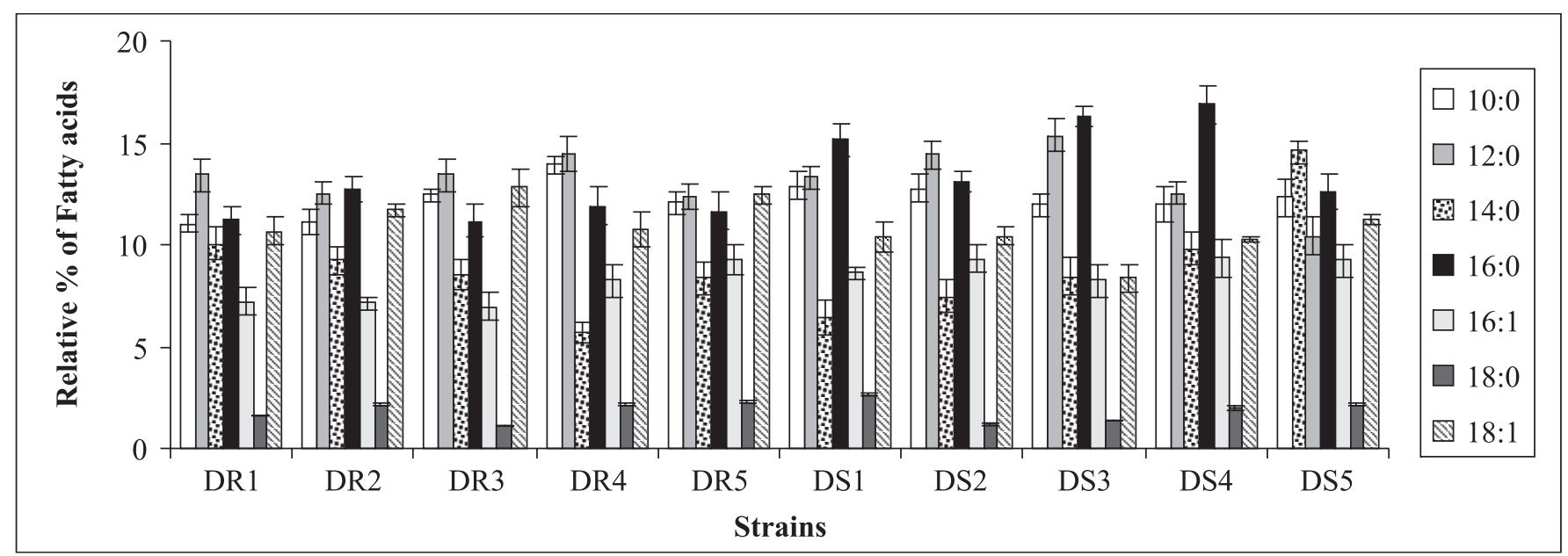

Figure 4. Relative percentage of fatty acids of azole resistant and susceptible strains of Candida albicans isolated from diabetic patients. Each value in the figure is the mean of three independent experiments. 


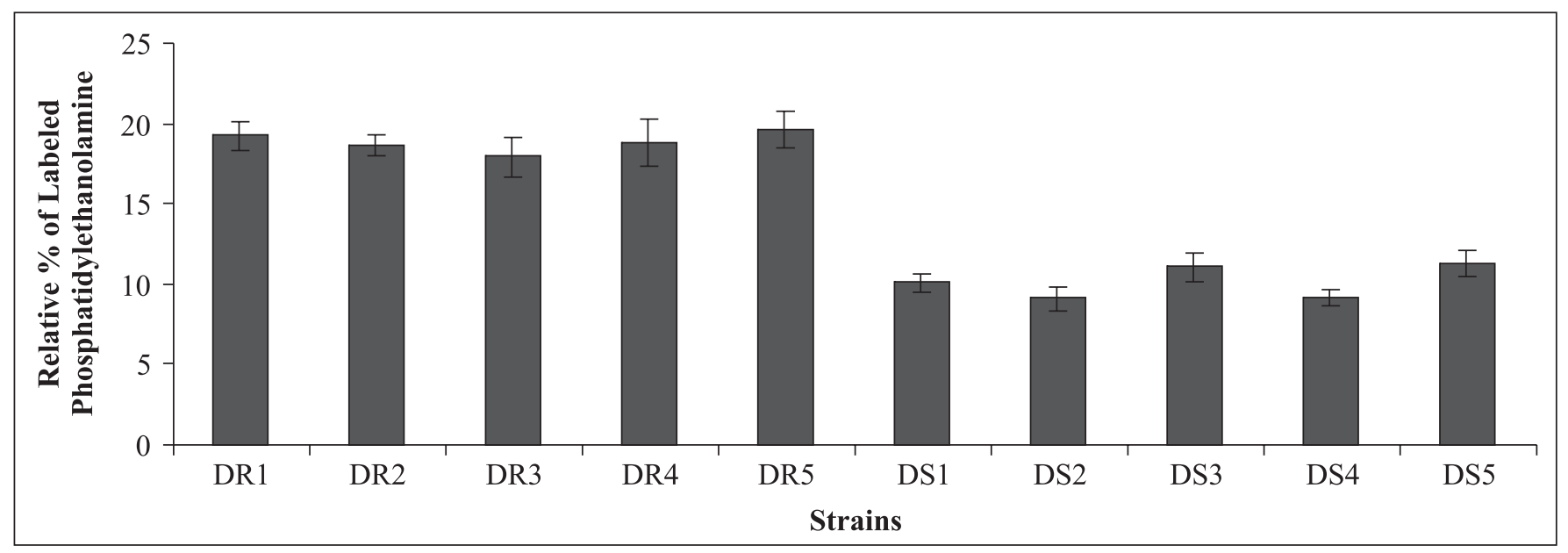

Figure-5. Percentage of phosphatidylethanolamine exposed in the outer leaflet of membrane in azole resistant and susceptible strains of Candida albicans isolated from diabetic patients as determined by fluorescamine labeling. Each value in the figure is the mean of three independent experiments.

in the cytoplasmic leaflet of the lipid bilayer, therefore the dye could label only externalized phosphatidylethanolamine as small percentage of this aminophospholipid is also present in outer monolayer (8). These experiments revealed that the percentage of exposed phosphatidylethanolamine was higher in the resistant strains, compared to susceptible isolates indicating a higher functional activity of Cdr1p. Higher percentage of exposed phosphatidylethanolamine has earlier been correlated with maximum expression of CDR1. In this study, the membrane fluidity of resistant strains was higher and it may be an important factor regulating phospholipid translocation mediated by overexpressed CDR1. Dogra et al. (8) have earlier demonstrated the involvement of Cdrlp in phospholipid translocation. The conclusion was based on the fact that an increased externalization of phosphatidylethanolamine in the outer leaflet of the plasma membrane of the mycelial form correlated well with CDR1 expression which was also more pronounced in mycelia than in the bud form of $C$. albicans, further confirming causal relationship between $C D R 1$ expression and phospholipid translocation.

The results obtained on these isolates have demonstrated clearly that increased membrane fluidity in resistant strains is probably either due to decreased content of ergosterol or increased overexpression of $C D R 1$ and $C D R 2$ genes, and/or both, suggesting that any change in membrane lipid composition and asymmetry would have direct bearing on drug resistance in clinical isolates of C. albicans.

\section{ACKNOWLEDGEMENT}

NNM is thankful to Prof. Rajendra Prasad for providing necessary facility to carry out the entire work in Membrane
Biology Lab, School of Life Sciences Jawaharlal Nehru University, New Delhi, India. Prof. Randhir Singh, CSIR Emeritus Scientist, Kurukshetra University, Kurukshetra, India is thanked for critically going through the manuscript and making valuable suggestions.

\section{RESUMO}

\section{Fluidez e composição lipídica da membrana de cepas de Candida albicans resistentes e sensíveis ao fluconazol, isoladas de pacientes diabéticos}

Dez isolados clínicos, sendo cinco resistentes e cinco sensíveis ao fluconazol, obtidos de pacientes diabéticos, foram estudados quanto à fluidez e composição química da membrana. Quando comparados aos isolados sensíveis ao fluconazol, os isolados resistentes apresentaram fluidez de membrana aumentada, conforme mensurado pela técnica de polarização fluorescente. A fluidez de membrana aumentada refletiu-se pelos valores mais baixos de p. Por outro lado, os isolados sensíveis continham quantidades mais elevadas de ergosterol, quase o dobro dos isolados resistentes, o que pode ter contribuído para a fluidez de membrana mais baixa. Entretanto, não se observou alteração significativa na composição fosfolipídica e de ácidos graxos nesses isolados. Experimentos de marcação com corante fluorescamina indicaram que a porcentagem de aminofosfolípides e fosfatidiletanolamina expostos foi mais elevada nos isolados resistentes do que nos sensíveis, indicando uma possível superexpressão dos genes $C D R 1$ e $C D R 2$ nos isolados resistentes. Os resultados aqui apresentados sugerem que alterações no teor de ergosterol e superexpressão dos genes 
ABC transportadores $C D R 1$ e $C D R 2$ podem contribuir na resistência ao fluconazol em isolados de $C$. albicans de pacientes diabéticos.

Palavras-chave: Fluidez da membrana, composição lipídica, resistência a azois, pacientes diabéticos

\section{REFERENCES}

1. Ansari, S.; Gupta, P.; Mohanty, S.K.; Prasad, R. (1993). The uptake of amino acids by erg mutants of Candida albicans. J. Med. Vet. Mycol., 31, 377-386.

2. Arthington-Skaggs, B.A.; Jradi, H.; Desai, T.; Morrison, C. J. (1999). Quantitation of ergosterol content: novel method for determination of fluconazole susceptibility of Candida albicans. J. Clin. Microbiol., 37, 3332-3337.

3. Boken, D.J.; Swindells, S.; Rinaldi, M.G. (1993). Fluconazoleresistant Candida albiacns. Clin. Infect. Dis., 17, 1018-1021.

4. Cannon, R.D.; Tsao, S.; Ong, S.; Niimi, K.; Lamping, E.; Monk, B.C.; Holmes, A.R. (2004). Allelic variation affecting drug pump function in Candida albicans. ASM Confrence on Candida and candidiasis. Austin, TX, Abstract no. 147(C).

5. Debry, P.; Nash, E.A.; Nekalson, D.W.; Metherall, J.E. (1997). Role of multidrug resistance P-glycoproteins in cholesterol esterification. J. Biol. Chem., 272, 1026-1031.

6. Decottignies, A.; Grant, A.M.; Nichols, J.W.; Wet, H.De.; McIntosh, D.B.; Goffeau, A. (1998). ATPase and multidrug transport activities of the overexpressed yeast ABC protein Yor1p. J. Biol. Chem., 273, $12612-12622$.

7. Diaz, C.; Schroit, A.J. (1996). Role of translocases in the generation of phosphatidylserine asymmetry. J. Membr. Biol., 151, 1-9.

8. Dogra, S.; Krishnamurthy, S.; Gupta, V.; Dixit, B.L.; Gupta, C.M.; Sanglard, D.; Prasad, R. (1999). Asymmetric distribution of phosphatidylethanolamine in C. albicans: possible mediation by $C D R 1$, a multidrug transporter belonging to ATP binding cassette (ABC) superfamily. Yeast, 15, 111-121.

9. Ferte, J. (2000). Analysis of the tangled relationships between Pglycoprotein mediated multidrug resistance and the lipid phase of the cell membrane. Eur. J. Biochem., 267, 277-294.

10. Fox, R.; Neal, K.R.; Leen, N.L.S.; Ellis, M.E.; Mandal, B.K. (1991). Fluconazole resistant Candida in AIDS. J. Infect., 22, 201-204.

11. Ghannoum, M.; Rice, L.B. (1999). Antifungal agents, mode of action, mechanism of resistance and correlation of these mechanisms with bacterial resistance. Clin. Microbiol. Rev., 12, 501-512.

12. Haque A.; Rai V.; Bahal B.S.; Shukla S.; Lattif A.A.; Mukhopadhyay, G.; Prasad, R. (2007). Allelic variants of ABC drug transporter Cdrlp in clinical isolates of Candida albicans. Biochem. Biophys. Res. Commun., 352, 491-7.

13. Hitchcock, C.A.; Barrett-Bee, K.; Russe, N.J. (1986). The lipid composition of azole-susceptible and azole-resistant strains of Candida albicans. J. Gen. Microbiol., 132, 2421-2431.

14. Hitchcock, C.A.; Russel, N.J.; Barrett-Bee, K.J. (1987). Sterols in Candida albicans mutants resistant to polyene or azole antifungals, and of adouble mutant C. albicans. CRC Crit. Rev. Microbiol., 15, 111-115.

15. Hitchcock, C.A. (1993). Resistance of Candida albicans to azole antifungal agents. Biochem. Soc. Trans., 21, 1039-1047.

16. Ibrahim, A.S.; Ghannoum, M.A. (1996). Chromatographic analysis of lipids, p. 52-79. In R. Prasad (ed.), Manual on membrane lipids. SpringerVerlag, Berlin, Germany.

17. Kaur, R.; Bachhawat, A.K. (1999). The yeast multidrug resistance pump, Pdr5p, confers reduced drug resistance in erg mutants of Saccharomyces cerevisiae. Microbiology, 145, 809-818.
18. Kakeya, H.; Miyazaki, Y.; Miyazaki, H.; Nyswaner, K.; Grimberg, B.; Bennet, J.E. (2000). Genetic analysis of azole resistance in the Darlington strain of Candida albicans. Antimicrob. Agents Chemother., 44, 2985-2990.

19. Kitchen, V.S.; Savage, M.; Harris J.R.W. (1991). Candida albicans resistance in AIDS. J. Infect., 22, 204-205.

20. Kohli, A.; Smriti, Mukhopadhyay, K.; Rattan, A.; Prasad, R. (2002). In vitro low-level resistance to azoles in Candida albicans is associated with changes in membrane lipid fluidity and asymmetry. Antimicrob. Agents Chemother., 46, 1046-1052.

21. Loffler, J.; Einsele, H.; Hebart, H.; Schumache, U.; Hrastnik, C.; Daum, G. (2000). Phospholipid and sterol analysis of plasma membranes of azole-resistant Candida albicans strains. FEMS Microbiol. Lett., 185, 59-63.

22. Marichal, P. (1999). Mechanism of resistance to azole antifungal compounds. Curr. Opin. Antiinfect. Invest. Drugs, 1, 318-333.

23. Metherall, J.E.; Li, H.; Waugh, K. (1996). Role of multidrug resistance P-glycoproteins in cholesterol biosynthesis. J. Biol. Chem., 271, 2634-2640.

24. Mukhopadhyay, K.; Kohli, A.; Prasad, R. (2002). Drug Susceptibilities of yeast cells are affected by membrane lipid composition. Antimicrob. Agents Chemother., 12, 3695-3705.

25. Perea, S.; Lopez-Ribot, J.L.; Kirkpatrick, W.R.; McAtte, R.K.; Santillan, R.A.; Martinez, M.; Calabrese, D.; Sanglard, D.; Patterson, T.F. (2001). Prevalence of molecular mechanism of resistance to azole antifungal agents in Candida albicans strains displaying highlevel fluconazole resistance isolated from human immunodeficiency virus - infected patients . Antimicrob. Agents Chemother., 45, 26762684.

26. Posteraro B.; Sanguinetti M.; Sanglard, D.; La Sorda, M.; Boccia, S.; Romano, L.; Morace, G.; Fadda, G. (2003). Identification and characterization of a Cryptococcus neoformans ATP binding cassette (ABC) transporter-encoding gene, CnAFRl, involved in the resistance to fluconazole. Mol. Microbiol., 47, 357-71.

27. Prasad, R.; Kapoor, K. (2005). Multidrug resistance in yeast Candida. Int. Rev. Cytol., 242, 215-248.

28. Redding, S.; Smith, J.; Farinacci,G.; Rinaldi, M.; Fothergill, A.; RhineChalberg, J.; Pfaller, M. (1994). Resistance of Candida albicans to fluconazole during treatment of oropharyngeal candidasis in a patient with AIDS: documentation by in vitro susceptibility testing and DNA subtype analysis. Clin. Infect. Dis., 18, 240-242.

29. Ruhnke, M.; Eigler, A.; Teenagen, I.; Geiseler, B.; Engelmann, E.; Trautmann, M. (1994). Emergence of fluconazole - resistant strains of Candida albicans in patients with recurrent oropharyngeal candidosis and human immunodeficiency virus infection. J. Clin. Microbiol., 32, 2092-2098.

30. Sanguinetti, M.; Posteraro, B.; Fiori, B.; Ranno S.; Torelli R.; Fadda G. (2005). Mechanisms of azole resistance in clinical isolates of Candida glabrata collected during a hospital survey of antifungal resistance. Antimicrob. Agents Chemother., 49, 668-679.

31. Sanglard, D.; Odds, F.C. (2002). Resistance of Candida species to antifungal agents: molecular mechanisms and clinical consequences. Lancet Infect. Dis., 2, 73-85

32. Semighini, C.P.; Marins, M.; Goldman, M.H.; Goldman, G.H. (2002). Quantitative analysis of the relative transcript levels of ABC transporter Atr genes in Aspergillus nidulans by real-time reverse transcription-PCR assay. Appl Environ. Microbiol., 68, 1351-7.

33. Sharom, F.J. (1996). The P-glycoprotein multidrug transporter: interactions with membrane lipids, and their modulation of activity. Biochem. Soc., 25, 1088-1096.

34. Smriti, Krishnamurthy, S.; Prasad, R. (1999). Membrane fluidity affects functions of Cdr1p, a multidrug $\mathrm{ABC}$ transporter of Candida albicans. FEMS Microbiol. Lett., 173, 475-481.

35. Mukhopadhyay, K.; Prasad, T.; Saini, P.; Pucadyil, T.J.; Chattopadhyay, A.; Prasad, R. (2004). Membrane sphingolipid - 
ergosterol interaction are important determinants of multidrug resistance in Candida albicans. Antimicrob. Agents Chemother, 48: $1778-1787$

36. Prasad, T.; Saini, P.; Gaur, N.A.; Vishwakarma, R.A.; Khan, L.A.; Haq, Q.M.; Prasad, R. (2005). Functional analysis of CaIPT1, a sphingolipid biosynthetic gene involved in multidrug resistance and morphogenesis of Candida albicans. Antimicrob. Agents Chemother., 49: 3442-3452.

37. Prasad, T.; Chandra, A.; Mukhopadhyay, C.K.; Prasad, R. (2006) Unexpected link between iron and drug resistance of Candida spp.: iron depletion enhances membrane fluidity and drug diffusion, leading to drug-susceptible cells. Antimicrob. Agents Chemother., 50: $3597-3606$

38. White, T.C.; Holleman, S.; Dy, F.; Mirels, L.F.; Stevens, D.A. (2002). Resistance mechanism in clinical isolates of Candida albicans. Antimicrob. Agents Chemother., 46, 1704-1713.

39. Xiao, L.; Madison, V.; Chau, A.S.; Loebenberg, D.; Palermo, R.E.; McNicholas, P.M. (2004). Three-dimensional models of wild- type and mutated forms of cytochrome P450 14-sterol demethlase from Aspergillus fumigatus and Candida albicans provide insights into posaconazole binding. Antimicrob. Agents Chemother., 48, 568574 . 